\title{
Resenha
}

Giobelinna Brumana, Fernando. O Sonbo Dogon. Nas origens da Etnologia francesa. Prefácio de Fernanda Arêas Peixoto. São Paulo, Edusp, 2012, 367 pp.

\section{Do pesadelo ao orgasmo: o segredo na história da antropologia}

Frederico Delgado Rosa

Universidade Nova de Lisboa

Fernando Giobellina Brumana retoma um tema recorrente, fazendo já parte do reportório das discussões clássicas da Antropologia que atravessam diferentes gerações e quase se transformam em mito disciplinar. Não se trata somente dos Dogon e da célebre cosmogonia de Marcel Griaule, mas sobretudo da crítica à sua obra, um trabalho de desconstrução inaugurado no início dos anos 1970 e desde então avolumado por uma série de contribuidores que, em conjunto, têm vindo a abalar seriamente a reputação prévia do personagem. Mais que fazer o historial desta tradição, Giobellina Brumana insere-se nela e como que a reinventa, utilizando a questão dos pecados de Marcel Griaule para partilhar uma reflexão pessoal sobre o eterno dilema da relação entre observadores e observados, sobre o que deve ou não deve ser a etnografia enquanto processo e resultado, e sobre o sentido, enfim, da Antropologia.

Se não soubéssemos quão imprevisível é o futuro da nossa disciplina, poderíamos dizer que este livro dá o golpe de misericórdia em Griaule. Em qualquer caso, faz mais que isso, na medida em que a apreciação paralela da obra e da figura de Michel Leiris, também lendárias, é o recurso escolhido e praticamente necessário para que a dita reflexão se desenvolva, criando um original sistema de oposições (que de forma um tanto divertida, embora não gozadora, Giobellina Brumana apelida de lévi-straussiano) entre os dois etnólogos franceses. Apesar da riqueza informativa e documental, não estamos perante um livro de história da disciplina em sentido estrito, mas, sobretudo, perante uma obra que 
utiliza essa história para fazer antropologia. Giobellina Brumananão está preocupado em se afirmar como historiador, preferindo tomar partido, de forma assumida, quase provocatória. Que não restem dúvidas: o autor admira a obra de Leiris tanto quanto despreza (não há outro termo) a de Griaule. Vejamos um pouco o porquê desse extremar de posições sobre os protagonistas da famigerada Missão Dacar-Djibuti de 1931-1933, alegadamente inauguradora do terreno da Etnologia francesa - o qual representa um desafio lançado aos antropólogos de hoje.

O âmago da questão, e por conseguinte do livro, é por um lado a busca e o resgate da autenticidade africana, enquanto objetivos centrais da Missão, e, por outro lado, a sinceridade ou não do etnógrafo perante a experiência realmente vivida em campo, Tanto Leiris como Griaule partiram imbuídos de um espírito romântico de descoberta e salvação - salvação no papel, na fotografia, no filme - de um outro ainda puro, embora em vias de adulteração, o qual contrastaria, justamente pela sua autenticidade, com a África de pasquim e cabaré da imaginação parisiense. Mais ainda, Leiris partia esperançado de se libertar da inautenticidade ocidental, por conseguinte de se transformar através do diálogo com comunidades nativas detentoras de verdades antigas. Não é certo que Griaule almejasse uma metamorfose tão profundamente quanto Leiris, mas movia-o sem dúvida a crença na existência dessa verdade recôndita, como um segredo a desvendar, o qual seria no fundo a essência forçosamente mística da realidade social e cultural africana - em particular dos Dogon, de cujos atributos de secretismo, a começar pela língua secreta, o antropólogo já tinha, aliás, ouvido falar antes mesmo do encontro.

Sucede, porém, que Griaule, à frente da Missão, pôs em prática e incentivou em toda a equipa uma atitude predatória que legitimava a apropriação pela mesma do patrimônio material e imaterial nativo por quaisquer meios, da sedução à punição, da compra pura e simples à substituição física do insubstituível, sempre sob pretexto de justo pagamento e da urgência de salvar. Tratava-se, portanto, de um antropólogo/etnólogo para quem, como diz Giobellina Brumana, "o que importa é a coisa" (:196), querendo com isto referir-se à captura objetificada de uma essência dogon que estaria como que impressa nesse patrimônio, transmitido é certo pelas pessoas, mas em detrimento das pessoas, da vida realmente vivida, para ser ao invés conduzido ao lugar assético onde poderia ser apreciado e imortalizado: o arquivo europeu em sentido lato, incluindo o museu, naturalmente. Clifford, e não só, tentou ver na blitæ̌krieg etnográfica de Griaule uma espécie de intrusão assumida, deliberadamente geradora de uma espécie de tumulto criativo entre as partes, que de um ponto de vista pós-moderno poderia ser tido 
como recurso precursor das questões de reflexividade etnográfica. Giobellina Brumana, contudo, não deixa qualquer dúvida aos leitores que a intrusão de Griaule era tudo menos assumida e que, pelo contrário, os bastidores da Missão eram isso mesmo: não deveriam de forma alguma passar para os resultados.

Já Michel Leiris, ao testemunhar e mesmo ao participar nos atropelos coloniais e emocionais da equipe, nos despiques monetários, nas frustrações e provocações várias, associadas ao diálogo com os informantes, não fez nada menos que iniciar, em segredo, a escrita de um livro (L'Afrique fantôme, publicado em 1934) onde revelaria tudo aquilo que Griaule tentava camuflar: os podres da Missão, inclusive em prejuízo próprio, revelando fraquezas íntimas, como as de ordem sexual. Estavam agora em flagrante rota de colisão dois segredos: o que Griaule queria levar à cena depois de "descoberto", e o da comédia em que todos vinham participando para esse fim. Diz-nos Giobellina Brumana que, nessa primeira grande etapa da Missão - a qual, não esqueçamos, haveria ainda de atravessar o continente em direção à Etiópia - a lição aprendida por Leiris "não estava tão relacionada ao 'outro', e sim a 'si mesmo"' (:124), ou seja, a lição de que o etnógrafo se via obrigado a ser um ator. Embora viesse já suspeitando que os nativos também tiravam proveito do pesquisador branco, entrando num jogo de hipocrisias e interesses próprios, o verdadeiro alcance dessa impressão ainda estava para se manifestar.

Enquanto isso, Griaule compilava em fichas manuscritas os elementos que o levariam a escrever, entre outros, o famoso Dieu d'eau (publicado em 1948). Giobellina Brumana recapitula e acrescenta as bastas "provas de acusação" de que a cosmogonia dogon na versão do etnólogo francês é uma "narração romanceada, um percurso iniciático desenhado para o grande público" (:243), sem que de resto seja possível aceder ao discurso original e menos ainda vernacular, tanto de Ogotemmêli, convertido em arquétipo dos velhos sábios dogon, como de outros interlocutores. O trabalho de cotejamento entre aquela obra e as notas de campo revela em qualquer caso uma duvidosa manipulação, até mesmo censura, sempre na mira da encenação final do mito-espetáculo. E Giobellina Brumana vai ao ponto de desconfiar que Griaule, vistos os seus métodos de pressão sobre os informantes, terá suscitado narrativas até então inexistentes, a julgar, aliás, pela banalidade (e não profundidade) de algumas delas. "Não se trata, pois, da ficção que os pós-modernos enxergam em toda e qualquer etnografia", precisa o autor. "Aqui parece que se está operando uma ficção bem mais ficcional - ou fictícia - que o habitual” (:172).

Quando mesmo assim detectava falhas intransponíveis no discurso, Griaule atribuía-as ao fato de o sistema, apesar de preservado, estar já em processo de 
decomposição. Giobellina Brumana relembra que isso legitimava, na ótica do etnólogo francês, a agressividade dos métodos: se a humanidade (entenda-se a França) era a compradora, pouco importava que a Missão transformasse os Dogon em vendilhões, acelerando assim aquele processo. Em suma, havia em Griaule uma crença de que não só podia como devia manipular astuciosamente os nativos. Mas se a sua intenção era essa, a prática real terá sido bem mais complexa, nos diz o autor, porquanto Griaule esquecia, num misto de ingenuidade e arrogância, que os informantes também tiravam proveito dele. Giobellina Brumana não tem tanto em mente as contrapartidas financeiras, mas, sobretudo, as de prestígio, por haver fortes indícios de que os indivíduos mais atraídos pela Missão "não eram pessoas do centro, da estrutura, e sim da margem" (:204) - indivíduos que, por conseguinte, mais dividendos tirariam da bizarra associação àqueles estrangeiros ávidos de tudo, poderosos econômica e politicamente. Griaule terá, pois, construído uma imagem monolítica do mito e do rito dogon, com destaque para as máscaras e suas danças cerimoniais, como se tudo fora um equilíbrio ancestral e sistêmico, uma ordem sem resíduos, e não um espaço de trânsitos sociais, de interstícios, de margens e mesmo de desordem.

Tudo isso, se existia para Marcel Griaule, somente tinha lugar nos bastidores, no espaço de uma realidade distante dos seus interesses e dos seus instrumentos de preparação intelectual dos resultados, enquanto Michel Leiris, pelo contrário, deixou-se afetar precisamente pela realidade do encontro humano, obrigando-se a renunciar ao romantismo de encontrar o que (porventura, dizemos nós; sem dúvida, diz Giobellina Brumana) não existia: a autenticidade africana. Intuído entre os Dogon, esse duro embate ou metamorfose veio a consumar-se na segunda grande etapa da Missão, quando se envolve, em Gondar, na Etiópia, com uma sacerdotisa do culto de possessão zar, chamada Emawayish. É um momento alto do livro, que não apresentamos aqui na sua ordem exata, aquele em que o autor junta as fontes arquivísticas e secundárias à própria bibliografia de Leiris para retratar a atração exercida sobre este por essa mulher outra, fatal, da história da antropologia: por ela, encarnação última da miragem de verdade e autenticidade, o etnólogo francês esteve praticamente disposto a renunciar à científica comédia da etnografia, para apenas contemplar, viver e amar a alteridade. Emawayish, porém, também era comediante. As frequentes citações do próprio Leiris, escolhidas a dedo, funcionam no livro como chicotadas psicológicas: "Lembro da Emawayish esfregar a boca depois da xícara de sangue [sacrificial], sem a menor preocupação de mascarar o jogo, como algumas felatrizes profissionais quando lavam os dentes" (:141). Da boca de um "entusiasta de bordéis e 
prostitutas", isso não representava contudo uma forçosa decepção. Em nota de rodapé, que bem podia ter subido para o corpo do texto, Giobellina Brumana coteja essa tirada de 1932 com uma versão mais tardia, de 1939, em que Leiris afirmava que aquele momento pressagiava uma relação "mais íntima que qualquer ligação carnal” (idem). O encontro estava consumado: não com a alteridade sonhada, autêntica, mas com a teatralidade das ações e relações humanas em qualquer espaço e tempo. Não havia por que fabricar um espetáculo de bastidores escondidos, como estava tentando Griaule, quando a própria realidade era fingimento verdadeiro, inautenticidade partilhada.

Ao vislumbrarmos a forma como Leiris se encontrou a si mesmo no outro e deixou de reagir romanticamente ante a possessão zar, nós leitores de O Sonho dogon somos enfim confrontados com a profunda, notória rejeição do romantismo - essa velha tradição da Antropologia - por parte de Giobellina Brumana, para emergir ao invés, pujante, quase violenta, a sua sensibilidade sociológica: pura e simplesmente, o segredo africano, o segredo dogon não existe, nem nunca existiu na forma em que foi sonhado pelos europeus e colocado na gênese da Missão Dacar-Djibuti. Na senda de Simmel, mas evocando também as suas próprias pesquisas sobre a umbanda e o candomblé no Brasil, o autor se revela convicto de que o segredo não é uma coisa; é antes de tudo um diacrítico, "um mecanismo social de segregação destinado à conformação, manutenção e hegemonia de um segmento da sociedade" (:216). Eis o que Griaule, ao contrário de Leiris, não podia sequer imaginar, até porque de outra forma cairia automaticamente por terra seu projeto de revelação ao mundo da ancestral sabedoria dogon.

Giobellina Brumana reconhece que a Missão Dacar-Djibuti e em particular a obra de Griaule tiveram um impacto espantoso, tanto no panorama francês como na África pós-colonial: a sabedoria dogon foi aceite como prova da contribuição do gênio africano para a civilização universal. Essa é, contudo, uma história em que não se revê, uma história que de certa forma amaldiçoou Leiris e Emawayish na proporção em que glorificou Griaule e Ogotemmêli. Em desfecho da obra, o autor acaba fazendo sua própria revelação, que não desvendamos aqui, para não tirar o suspense. Apenas diremos que seu livro, de escrita empolgada e com uma estrutura mais sutil e poética que a exposta nesta recensão, é um contributo muito louvável para contrariar os excessos da crítica pós-moderna do projeto antropológico. O único receio que nos suscita é que o caminho sugerido seja demasiado confiante em determinado "progresso" teórico da disciplina em detrimento de sua componente ideográfica ou culturalista, e que, por conseguinte, não sejam deixadas em aberto, mas apreciadas em tom definitivo - ou pelo menos de uma assertividade quase 
FREDERICO DELGADO ROSA. DO PESADELO AO ORGASMO: O SEGREDO NA HISTÓRIA DA ANTROPOLOGIA

desconcertante - as potencialidades dos escritos do passado e as margens, sempre em transformação, da própria Antropologia.

\section{Referências bibliográficas}

CLIFFORD, James

1983 "Power and Dialogue in Ethnographie: Marcel Griaule's Initiation". In

StOcking, Jr., G. W. Observers Observed: Essays on Ethnographic Fieldwork. Madison, University of Wisconsin Press.

GRIAULE, Marcel

1966[1948] Dieu d'eau. Paris, Fayard.

LEIRIS, Michel

2007[1934] A Africa Fantasma. São Paulo, Cosac Naify. 